\title{
James Tooley, Really Good Schools: Global Lessons for High-Caliber, Low-Cost Education, Oakland: Independent Institute, 2021. xx + 404 pages. 29.95 USD (hardback)
}

\author{
Stephen G. Zimmer ${ }^{1}$
}

Accepted: 19 January 2022

(c) The Author(s), under exclusive licence to Springer Science+Business Media, LLC, part of Springer Nature 2022

There is perhaps no one else in the world who has done more to propagate the emergence of low-cost private schools in the developing world than James Tooley. His latest book, Really Good Schools: Global Lessons for High-Caliber, Low-Cost Education, continues the theme of his first groundbreaking book on low-cost private schools, The Beautiful Tree (Tooley 2013). While The Beautiful Tree mixes storytelling with data and analytical arguments to make the case for low-cost private schools, the focus of Really Good Schools is much broader. Here, Tooley includes updated data on low-cost private schools and expands his insights to critique how social scientists evaluate education.

The ongoing COVID-19 pandemic has exposed many faults in the US public school system. Many parents are questioning whether keeping their kids in public schools is worth the unpredictability of constant school closures and the difficulties with online lessons. The pandemic has also reignited the school choice debate regarding whether states should be more open to supporting charter schools, school vouchers, or education savings accounts. But are these the right debates we should be having with regards to education? In this book, Tooley connects the lessons learned from $20+$ years of documenting low-cost private schools in the developing world to education policy debates in the US and internationally.

The book is divided into three parts with an overarching theme for each. Part one addresses some criticisms Tooley received since the publication of The Beautiful Tree, namely that the schools he discovered were not really in the poorest areas of the world. To address his critics, Tooley documents his travels to areas of the world stricken by war and other conflicts. He evaluates the schools he discovered on five dimensions: scalability, affordability, value for money, equality, and sustainability in order to properly address is critics.

Stephen G. Zimmer

szimmer@gmu.edu

1 Department of Economics, George Mason University, Fairfax, VA, USA

Published online: 24 January 2022 
On the scalability dimension, he tracks schools in rural Liberia, Sierra Leone, and South Sudan and demonstrates that in many of these communities more than 70 percent of students are educated through a low-cost private school. Compared to public schools in the area, low-cost private schools are on paper slightly more expensive than public schools. However, once factors like transportation costs (low-cost private schools are often closer to poor neighborhoods), discounts (families often get "two-for-one" discounts), and relative value (students in low-cost private schools routinely outperform their government school counterparts) are taken into account, low-cost private schools are far more cost-effective than public schools.

Tooley also demonstrates low-cost private schools are more likely to treat students equally, contrary to what critics often argue. He shows that when 'unregistered' (read: low-cost private schools) schools are included in national statistics, they overwhelmingly have a higher proportion of female students compared to public government schools. In order to argue low-cost private schools are sustainable in the long term, Tooley describes the flood of investments towards low-cost private schools in the last 15 years that have created large scale companies like Bridge International Academies and Omega Schools (pp. 85-113). These companies created standardized and, more importantly, sustainable chains of low-cost private schools in developing countries.

In Part two, Tooley puts forward his most profound argument in the book: the reason why public and private schools are not as dynamic as other areas of the economy is because governments and international agencies around the world control the framework of education by controlling the standards for attendance, curriculum, and testing which influences how both public and private schools are designed. Ignoring this element is what leads to a lot of confusion when discussing education policy.

Tooley starts off by addressing two critics of education from opposite perspectives: Poor Economics by Banerjee and Duflo (Banerjee and Duflo 2012) and The Case Against Education by Caplan (Caplan 2018). Banerjee and Duflo rightly point out that parents of students in private schools place enormous pressure on schools to prepare students to pass national exams rather than prepare them with valuable skills. However, Tooley argues the issue is government control over the institutional framework, not necessarily private schools. In economic terms, private schools are merely responding to the demands of consumers in a market where output figures are determined by government bodies, rather than, say, profit and loss signals. Caplan makes a similar error, but from a different perspective. Caplan argues that education, from a social point of view, is wasteful because it is used primarily to signal traits rather than actually develop them. Tooley once again responds that this is a symptom of government imposed standards rather than a problem of education per se. Signaling is wasteful because governments control funding and the framework of education. Caplan misses the second part.

If government control of the framework of education is the problem, are there alternatives? Tooley draws on two examples - musical education and martial arts - to illustrate how other, more privatized, educational institutions fill this gap (pp. 165-177). Musical education and martial arts are governed by private organizations, which spontaneously created a progression system over the years. Both music students and martial arts students have examinations they must pass to progress to the 
next stage ("grades" for music and "belts" for martial arts) and are open to anyone at any age and any number of years' experience. These examples show that if private organizations like musical education and martial arts can establish testing and credentialling without government interference, there is a strong reason to believe that an education system without government control over testing and credentialling would find alternative ways to accomplish the same goal more efficiently.

Tooley closes the second part of the book with a suggestion for a new measure of education. The most widely used metric for educational quality in a nation are Programme for International Student Assessment (PISA) scores. Tooley argues that using metrics like this are akin to measuring inputs rather than genuine outputs. He suggests an, admittedly rudimentary, alternative index that encompasses what ought to be an aggregate measure of the quality of education. The index includes: suicides per 100,000 people (measure of happiness), GDP per hour worked (labor productivity), patents per capita (innovation/creativity), Democracy Index (strength of democratic institutions), crime index, and PISA scores (pp. 216-225). Together, the metrics in this index would more accurately measure whether an education system is improving the welfare of society based on a combination of factors it is supposed to be improving.

Part three discusses the state of education in America where Tooley shifts his attention to the ongoing school choice debate. ${ }^{1}$ While he is sympathetic to the arguments in favor of school choice programs (vouchers, charter schools, etc.), he is far less sanguine about its success thus far. He breaks down state-level data and shows that the growth of voucher programs over the years has not increased in the way Milton and Rose Friedman had hoped when they wrote Free to Choose (pp. 255276; Friedman and Friedman 1980). Tooley closes the book by arguing we should treat education as a spontaneous order rather than a planned order, as it is often treated by policymakers (pp. 327-348). School systems in the US and UK in the $19^{\text {th }}$ century were for the most part spontaneous creations that were slowly taken over by state governments by the end of the century (West 1965). There is no reason to believe a robust market for education cannot exist in the $21^{\text {st }}$ century if national governments were to give up control over the framework of education.

Overall, Really Good Schools is a refreshingly original take on the state of education in the world today. There are only a couple of weaknesses in the book that are worth mentioning. First, in chapter 14, Tooley addresses the question 'why are there no low-cost private schools in America?' He dismisses some often cited reasons, among them being that public schools crowd out genuine private schools and that the regulatory environment for opening a low-cost private school makes doing so impossible. However, Tooley does not offer his explanation why low-cost private schools have not emerged in America. Economists are inherently skeptical of $\$ 100$ bills lying on the sidewalk without an explanation as to what is preventing someone from picking it up. By not including a reason why no one has bothered to pick up the $\$ 100$ bill, or at least admitting that he does not know why, his analysis in this part of

\footnotetext{
${ }^{1}$ Really Good Schools was finished in the very early stages of the COVID-19 pandemic, so his insights here do not include changes that have resulted since then.
} 
the book is incomplete. Finally, the ending to the book is rather sudden. If the book had a tidier ending by summarizing his findings or leaving readers with questions for further research, the book would have had a stronger finish.

Tooley's work should be of interest to economists, especially Austrian economists, as he presents a unique case for examining education through the lens of comparative institutional analysis. He finds himself in a peculiar position where he disagrees with the conventional view that education ought to be left purely up to government control, but is also hesitant to join the school choice bandwagon. At the end of the day, Tooley is arguing that institutions matter - a point that is often lost on both sides of education debates in the $21^{\text {st }}$ century. How schools are funded and what is taught are no doubt important matters. But a far more important and underappreciated question is who controls the institutional framework of education? By focusing on the institutions that govern both public and private schools, economists can better understand how entrepreneurial discovery is redirected in unproductive directions or stifled altogether. If economists and other social scientists want to truly understand why education systems are the way they are, they should shift their attention to this question.

\section{References}

Banerjee, A. V., \& Duflo, E. (2012). Poor Economics: A Radical Rethinking of the Way to Fight Global Poverty. Public Affairs.

Caplan, B. (2018). The Case against Education: Why the Education System Is a Waste of Time and Money. Princeton University Press.

Friedman, M., \& Friedman, R. (1980). Free to Choose: A Personal Statement. Harcourt Brace Jovanovich.

Tooley, J. (2013). The Beautiful Tree: A Personal Journey into How the World's Poorest People Are Educating Themselves. Cato Institute.

West, E. G. (1965). Education and the State: A Study in Political Economy. The Institute of Economic Affairs.

Publisher's note Springer Nature remains neutral with regard to jurisdictional claims in published maps and institutional affiliations. 